\title{
Dynamics of Land use Around the Micro-Dam Anti-Salt in the Sub-Watershed of Agnack Lower Casamance (Senegal)
}

\author{
Hyacinthe Sambou $^{1,2}$, Bienvenu Sambou ${ }^{1}$, Ramatoulaye Mbengue ${ }^{2,3}$, Mamadou Sadio ${ }^{2,3}$, \\ Pierre Corneille Sambou ${ }^{2,3}$ \\ ${ }^{1}$ Institute of Environmental Sciences, Faculty of Science and Technology, University Cheikh Anta Diop., Dakar-Fann, Senegal \\ ${ }^{2}$ Teaching Laboratory and Research in Geomatics, Campus of Polytechnic High School of Dakar, Cheikh Anta Diop., Dakar-Fann, Senegal \\ ${ }^{3}$ Department of Geography, Faculty of letters and Social Sciences, University Cheikh Anta Diop., Dakar-Fann, Senegal
}

\section{Email address:}

sambouzeb@yahoo.fr (H. Sambou), bienvenu.sambou@ucad.edu.sn (B. Sambou)

\section{To cite this article:}

Hyacinthe Sambou, Bienvenu Sambou, Ramatoulaye Mbengue, Mamadou Sadio, Pierre Corneille Sambou. Dynamics of Land use Around the Micro-Dam Anti-Salt in the Sub-Watershed of Agnack Lower Casamance (Senegal). American Journal of Remote Sensing.

Vol. 3, No. 2, 2015, pp. 29-36. doi: 10.11648/j.ajrs.20150302.12

\begin{abstract}
Agriculture, mainly based on rain, is one the most important economic activities in Lower Casamance region. Its agricultural production is vulnerable to climatic variability. The water management has become an important issue for rural populations food security. This research aims at the characterization of environmental evolution and agricultural production, around the anti-salt micro-dams in Lower Casamance area, which has a high rainfall and a rich potential of water resources. This study examines the hydro-agricultural planning issues in Lower Casamance and aims at the analysis of the land use change and its evolution in the Agnack sub-basin around anti- salt micro-dam between 1984 and 2010 . Based on the importance of rice production area around micro-dams, the analysis focus on eight sites. Using satellite imagery Landsat TM of 1984 and 1992 and ETM of 2000 and 2010 combined with ground, socio-economic survey and soil analysis data, this research investigates land use change through image classifications, change detection and landscape pattern analysis. We conducted a mapping of the rice paddies to determine the evolution of riceland during these dates. Through a pseudo-supervised classification coupled with field data, we characterized the different types of land use and cover. Results of land use/cover change analysis showed a decrease of riceland area; while there is a relative vegetation regeneration between 1984 and 2010. The soil analysis showed a deterioration in soil quality which is showed by a very high acidity in all sites and a soil salinity of riceland in the upstream developed valleys. Socio-economic surveys showed the importance of the micro-dams. In the term, the micro-dam did not achieve the expected results. It could not solve the problem of degraded soil desalination and intensification of rice growing.
\end{abstract}

Keywords: Lower Casamance, Land Use, Remote Sensing, Satellite Imagery, Mapping, Anti-Salt Micro-Dams, Rice Growing

\section{Introduction}

Lower Casamance, is located in the southern of Senegal, in the region of Ziguinchor. It covers an area of 7,339 $\mathrm{km} 2$. In terms of climate, it belongs to coastal South Sudanese domain [1], which, in this position, makes it one of the wettest areas of Senegal. It is crossed by many rivers and valleys during (the Casamance River and its tributaries) with a concentration of surface and subsurface runoff and promoting cultivation of these depressions. Lower Casamance is subject to salinization exacerbated by climate variability, since 1968 marked by a significant decline in rainfall and a change of water regime and reduced flows of the Casamance River and its tributaries [2] and [3]. Some of the valleys are also marked in their operation by a deep invasion of the sea inland because of the low slopes (less than $1 \%$ ). Agricultural activities, the main sources of income and food for the population are affected. Therefore, controlling perceived as a strategy to secure rice production water, resulting in the development of small hydro-agricultural works of traditional design. The purpose of these hydraulic micro-structures is profitable for some of 
those affected by salinization and rainfall deficit to intensify rice production valleys. These various questions: salinization lowlands and valleys, evolution of rice and production of anti-salt Low Casamance micro-dams, raised in the 1960s the interest of many researchers including [4]; [5]; [6]; [7]; [8]; [9]; [10]; [11]; [12]; [13]; [14]; [15]; [16]. Moreover, the construction of modern anti-salt micro-dams has been known in here in the last two decades. The proliferation of these types of structures accentuates the change in land use, been little work in the area. This theme has become essential in most cartographic inventory and monitoring of environmental phenomena [17]. And this is because the planning and monitoring of rice spaces are a constant concern of those involved in the management of water resources, we undertook this study of Ebinkine sub-watershed, characterized by a predominance of rice (over $80 \%$ ). The main activity is influenced by climatic factors that induce significant changes. Remote sensing is an appropriate tool to understand the spatio-temporal changes of land use [18]. With their wide spatial coverage, high repeatability and low cost, Landsat images are preferred data to identify differences zone status by observing at different dates [19]. The use of satellite data for mapping land cover change is now widespread [20], especially as the maximum time interval of thirty years for Landsat images. The main factors limiting the sensing changes are differences in weather conditions, geometry acquisition and ground conditions [21] and [22]. In addition, the strong dependence of the spectral characteristics is one of the main reasons for the lack of reliability of the classified map[23]. To overcome this constraint own remote sensing, we relied on field data to improve the classification accuracy and reliability of land obtained from Landsat data from land data in1984, 1992, 2000 and in 2010 cards.

\section{Presentation of the Study Area}

The study area covers the sub watershed of Agnack located between $12^{\circ} 31^{\prime} 0^{\prime \prime}$ and $12^{\circ} 39$ ' 0 "north latitude and between $15^{\circ} 56^{\prime} 30^{\prime \prime}$ and $16^{\circ} 9^{\prime} 0^{\prime \prime}$ of west longitude, in the rural community of Adeane, Ziguinchor. This sub-basin is crossed by numerous valleys. It is the watershed backwater Sindone a slope of $0.013 \%$. It spreads over $65 \mathrm{~km}$ from NE to SW and 40 $\mathrm{km}$ from NW to SE, with low elevations (from 0 to 37 meters). Impoundment was in 2004 with the aim to promote the intensification of rice by desalination of rice paddies.

\section{Material and Method}

\subsection{Climate Data}

The rainfall station of Niaguis is commissioned in 1975 as that of Tenghory. It covers the sub-watersheds of Agnack. It has a series of 36-year-long observations. It is characterized by two periods. Adry period with negative variances and a wet period with positive deviations. The dry period in question runs from 1975 to 1993 (Figure 1). Inside the dry season, there is a degradation of rainfall which peaked in $1977(740 \mathrm{~mm})$. Degradation of rainfall diminishes the pure and as we approach 2000. The wet period is from 1994 to 2011.

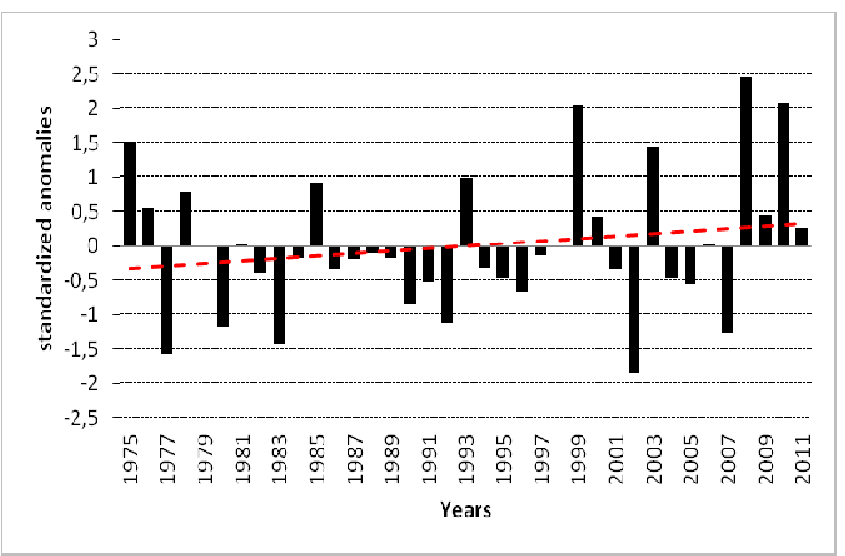

Figure 1. Standardized anomalies of annual rainfall at station Tenghory between 1975 - 2011.

Inside the wet period there are rainy years and less rainy years. The maximum rainfall occurred in 2008 with $1929 \mathrm{~mm}$, the minimum in 2002 with $662 \mathrm{~mm}$. The general trend of rainfall is increasing.

\subsection{Measuring the Salinity of Rice Land}

To assess the impact of micro-dam on the salinity of rice land, a composite soil sampling was conducted randomly upstream of the anti-salt micro-dam. Samples are collected at the top $25 \mathrm{~cm}$ of soil. The determination of the salinity was carried out at the Laboratory of Analytical Methods to the Research Institute for Development (IRD) in Dakar.

\subsection{Satellite Data Used}

Mapping the land was based on Landsat TM (Thematic Mapper) on 26 November 1984 on 15 November 1991 and Landsat ETM + (Enhanced Thematic Mapper) from 01 December 2000 to 19 November 2010 (Table 1). The year 1984 was characterized by a drought, while 2010 was marked by a slight increase in rainfall. The images were selected during the end of the rainy season period to minimize exaggerations canopy related to herbaceous; the date of mid-November and December after being [24] a period characterized by a ground cover related to the density of woody vegetation. In addition, the advantage of the dry season is to have a low cloud cover. Images used are from the database of United State Geological Survey (USGS). Field observations on the types of vegetation and cultivation areas were made in November 2010. Auxiliary data (GPS surveys, topographic map at $1 / 50000$ interviews with rice) were obtained from fieldwork conducted between November and June 2010. Selection of training areas, is in the company of local farmers and takes into account of homogeneous entities, the land and vegetation cover. Surveys GPS points were used as bench marks. Using multidates image required atmospheric correction. Calibration strips have been used for this purpose. 
Image processing, including their calibration, carrying colorful compositions and supervised classification is based on the performance of the ENVI software while developing land use maps and changes has been made possible by GIS tools ArcGIS.

\subsection{Image Processing}

The use of multitemporal image required an atmospheric correction as advocated [25], [26]. The images were georeferenced and calibration bands was performed. To avoid mismatches due to the difference of Landsat and optimize the overlay images for diachronic analysis, data from 1984, 1992 and 2000 were rigged compared to the 2010 image corrected from GPS surveys . To detect changes occurred, we performed unsupervised classification in this trouble to facilitate the choice of the different classes. For further work, we perform a pseudo-supervised classification [27]. This model of classification is to perform successive partitions on a set of pixels and to isolate as the considered pixels is correctly classified. The choice of this method is due to the strong heterogeneity of the elements of the land in the sub-watershed and the likelihood of confusion of some components, namely the paddy not flooded and flooded paddy fields on the one hand the tanne rice and dewatered other parts. Hierarchical clustering begins by determining the number of classes and the selection of training plots to achieve a cartographic synthesis through a successive selection of top-ranked elements. The choice of the number of classes is based on the mapping information collected images, with field data collected, between November and June 2010. Deductions classes are also faced with external data that provides information on the nature of the soil occupation. To estimate the overall performance of the classification, 800 control points are collected in the field. This collection is performed prior to image processing at a rate of 20 to 50 points per class at the highest end of typology implementation for image processing.

Table 1. Satellite data used.

\begin{tabular}{lllll}
\hline Data & $\begin{array}{l}\text { Date of } \\
\text { acquisition }\end{array}$ & $\begin{array}{l}\text { Spectral } \\
\text { Range }(\mu m)\end{array}$ & $\begin{array}{l}\text { Nominal } \\
\text { Spectral } \\
\text { Location }\end{array}$ & Resolution(m) \\
\hline ETM $^{+}$ & $01 / 12 / 2000$ & $1 .[0.45-0.51]$ & Blue & $30 * 30$ \\
& $19 / 11 / 2010$ & $2 .[0.52-0.60]$ & Green & $30 * 30$ \\
& & $3 .[0.63-0.69]$ & Red & $30 * 30$ \\
& & $4 .[0.75-0.90]$ & Near-IR & $30 * 30$ \\
& & $5 .[1.55-1.75]$ & Mid-IR & $30 * 30$ \\
& & $6 .[10.40-12.50]$ & Thermal-IR & $60 * 60$ \\
& & $7 .[2.09-2.35]$ & Mid-IR & $30 * 30$ \\
& & $8 .[0.52-0.90]$ & Panchromatic & $15 * 15$ \\
& $26 / 11 / 1984$ & $1 .[0.45-0.52]$ & Blue & $30 * 30$ \\
& $15 / 11 / 1991$ & $2 .[0.52-0.60]$ & Green & $30 * 30$ \\
& & $3 .[0.63-0.69]$ & Red & $30 * 30$ \\
& & $4 .[0.76-0.90]$ & Near-IR & $30 * 30$ \\
& & $5 .[1.55-1.75]$ & Mid-IR & $30 * 30$ \\
& & $6 .[10.20-12.50]$ & Thermal-IR & $120 * 120$ \\
& & $7 .[2.08-2.35]$ & Mid-IR & $30 * 30$ \\
\hline
\end{tabular}

Points are defined by a random sample drawn from a regular grid of points spaced at $2 \mathrm{~km}$ covering the entire image and supplemented by stratified sampling for classes underestimated when sampling at random. The geographical coordinates of each point used to locate the field with a margin of error of between 3 and $5 \mathrm{~m}$ with a GPS map Garmin 62st.

\subsection{Cartographic Analysis}

The validation of the results obtained by supervised classification, from training plots, was done by determining the confusion matrices and the calculation of Kappa coefficients. This operation allowed to control the quality of the results, to assess the possible risk of confusion and better capabilities differentiate land cover classes [28]

The results obtained from the confusion matrices are satisfactory with percentages details of at least $88 \%$ and kappa coefficients higher than 0.86 for all processed images (Table 2).

Table 2. Accuracy Assessment of images classification.

\begin{tabular}{lll}
\hline Date of image & Kappa & Overall accuracy \\
\hline $26 / 11 / 1984$ & 0.87 & $89 \%$ \\
$15 / 11 / 1991$ & 0.91 & $92 \%$ \\
$01 / 12 / 2000$ & 0.86 & $91 \%$ \\
$19 / 11 / 2010$ & 0.89 & $91 \%$ \\
\hline
\end{tabular}

The result of the classification identified different classes of land cover. Names and definitions of occupation classes of vegetation cover resulting from the nomenclature [29]; [30]; [31] and [32].

\section{Results}

\subsection{State of Land Use between 1984and 2010}

The analysis of the evolution of land use in the Agnack's watershed through the presentation of ground cover maps respectively 1984, 1992, 2000 and 2010 and their respective statistics (Table 3).

The use of different dates images allowed to have information on the dynamics of the sub watershed. This diachronic study to highlight the changes that occurred during the reporting period (1984-2010).

In 1984, land use is dominated by vegetation mainly composed of dense dry forest, tree- savannah and shrub savannah. All the vegetation covers an area of 1,631.66 hectares, representing $71.2 \%$ of the entire sub-watershed (Figure $2 \mathrm{~A}$ ). The shrub savannah trees with 881.54 hectares is the largest plant formation. The paddy not flooded covering 249.62 hectares and accounted for only $10.9 \%$ of the sub basin area. The land use status in 1992 (Figure 2 B) shows relatively the same distribution as that of 1984 , with a predominance of vegetation. In 1992, shrub savannah experienced a decrease in estimated area of 212.04 hectares compared to 
Table 3. Evolution units of land in the Agnack's sub-watershed.

\begin{tabular}{lllllllll}
\hline Type of land cover & $\mathbf{1 9 8 4}$ hectares & $\mathbf{\%}$ & $\begin{array}{l}\text { Areas 1991 } \\
\text { hectares }\end{array}$ & $\mathbf{\%}$ & $\mathbf{2 0 0 0}$ hectares & $\mathbf{\%}$ & $\mathbf{2 0 1 0}$ hectares & \% \\
\hline Fields of peanut & 395,23 & 17,24 & 403,15 & 17,60 & 185,88 & 8,11 & 369,14 & 16,11 \\
Dense dry forest & 512,19 & 22,35 & 538,62 & 23,50 & 717,90 & 31,33 & 671,24 & 29,29 \\
Paddy not flooded & 249,62 & 10,90 & 191,00 & 8,33 & 198,58 & 8,67 & 201,45 & 8,80 \\
Tree-savannah & 237,93 & 10,40 & 454,70 & 19,82 & 792,40 & 34,58 & 734,30 & 32,04 \\
Shrub savannah & 881,54 & 38,47 & 669,50 & 29,22 & 359,04 & 15,67 & 299,91 & 13,09 \\
Tanne & & & 15,96 & 0,70 & 12,88 & 0,56 & 3,90 & 0,17 \\
Muddy wetland & 14,97 & 0,65 & 18,56 & 0,81 & 24,81 & 1,08 & 11,55 & 0,50 \\
Total & 2291,49 & 100 & 2291,49 & 100 & 2291,49 & 100 & 2291,49 & 100 \\
\hline
\end{tabular}

1984, while the area occupied by tree savannah experienced a substantial increase in 216.77 hectares.

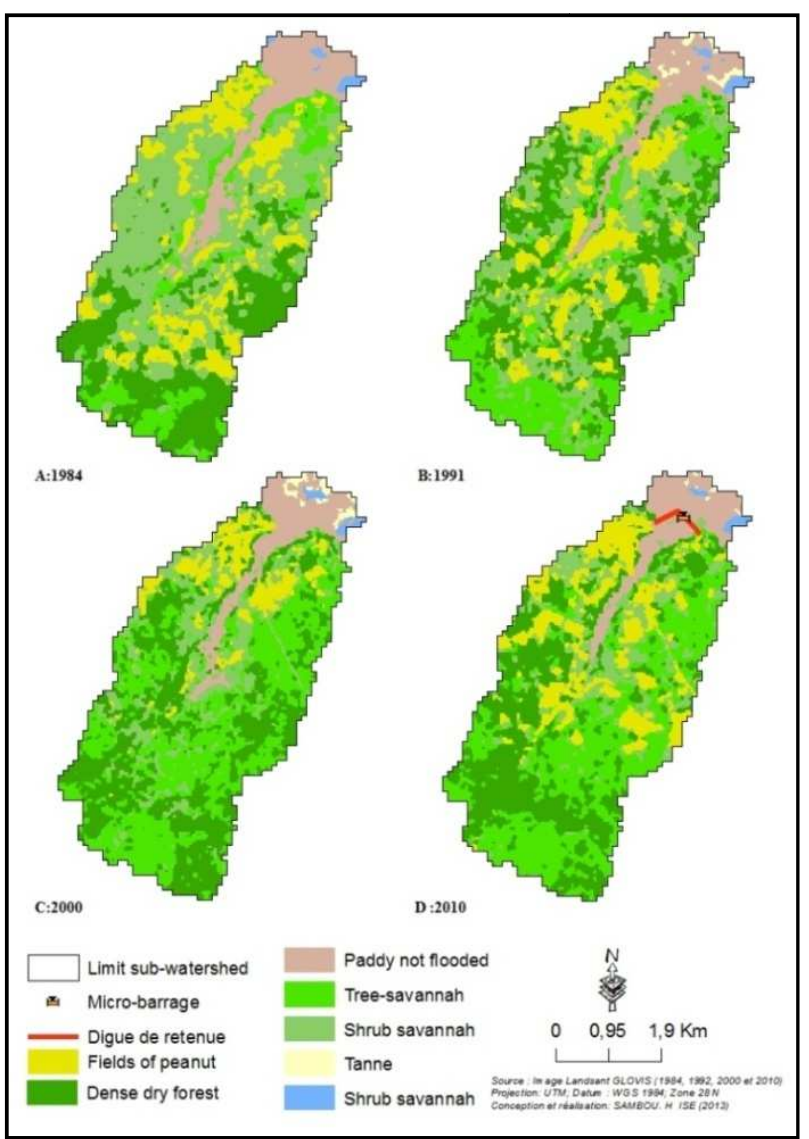

Figure 2. Land use in the Agnack's sub-watershed of in 1984 (A) 1991 (B) 2000 (C) 2010 (D).

This increase can be explained by the increasing rainfall and low population pressure on vegetation. Compared to 1984 , the area of not flooded decreased by $-2.57 \%$ between 1884 and 1992, while fields of peanut increased slightly (Figure 3).

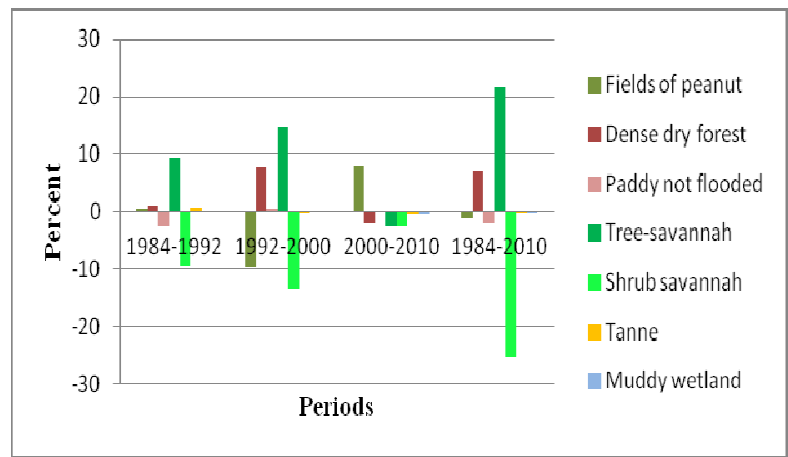

Figure 3. Evolution of land use in the Agnack's sub-watershed.

Reducing paddy not flooded area is related to the abandonment of rice fields affected by salinity accentuated by droughts known aware of the 1980-1990 decade.In 2000 (Figure $2 \mathrm{C}$ ), the area of dense dry forest has increased by 179.28 hectares. Similarly, the tree-savannah increased 337.7 hectares or $14 \%$ of its area (Figure 3 ). This result is explained by the flight of local populations in the watershed to the city of Ziguinchor for reasons of insecurity linked to the Casamance crisis. The sub watershed is Agnack porch of the Republic of Guinea Bissau, in a deemed hazardous area especially during the period of 1990-2000. Woody species colonized the abandoned fields by the population. Unlike the dense dry forest and tree savannah, shrub savannah by around (46.37\%) or $13 \%$ of its area (Figure 3 ). Shrub savannah being closer to homes and more accessible, suffered strong pressure from the people who stayed there. The same situation may explain the decline in the size of fields of peanut. During 2010 the vegetation (dense dry forest, tree savannah and shrub savannah) was reduced as a whole. The tree savannah and shrub savannah have recorded the largest decrease, or almost $-2 \%$ of their areas (Figure 3 ). Human pressure is the primary factor in the degradation of dry forest. The lull in the Casamance crisis, between 2000 and 2010, favored the return of the population on the one hand exerts pressure on the vegetation and also resumed their rice production. This helped to decrease the size of the vegetation and increased that of dewatered rice and fields of peanut between 2000 and 2010 . 
The increase in the area of dewatered rice was carried out in the downstream part of the anti- salt micro-dams. In the upstream part, rice cultivation is no longer practiced, despite the construction of anti-salt; because of the persistence of salinity and the failure of the work book that cannot hold water.

The result of the analysis of the extent of salinity, in the upstream valley of the anti-salt micro-dam, showed that, despite the introduction of anti-salt micro-dam, salinity in the valley Agnack grains ground and is slightly higher in some places thereof. The salinity varies upstream of anti-salt micro-dam between 0.4 and $1 \%$ in places reaching rates of 2 to $2.10 \%$. Its highest rate $(8.2 \%$ ) is observed at a distance of 600 meters upstream from the anti-salt micro-dam (Figure 4). This can be explained by a lack of salt-affected soils leaching already before the construction of anti-salt dam. This has fostered a hair recovered salt. In addition, the lack of maintenance of the anti-salt structure caused at the failure of valves that have become defective, let in salt water from downstream to upstream period of living water.

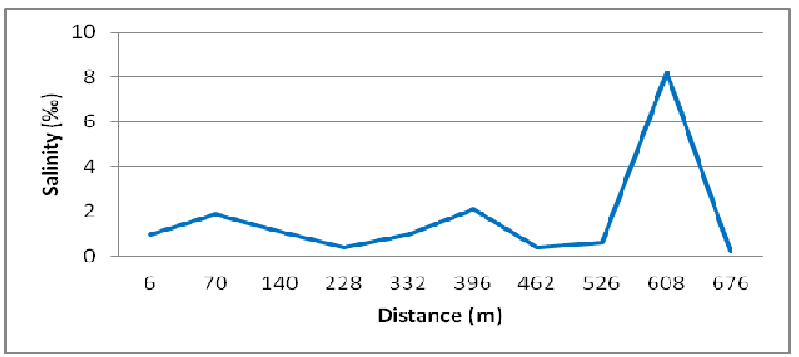

Figure 4. Evolution of salinity upstream of the micro-dam.

\subsection{Analysis of Changes in Land Use in the Agnack's Sub Watershed}

The matrix changes, generated by the crossing of the ground cover maps of 1984 and 1992 under Agnak watershed, shows an evolution in the different classes of land cover. Over forty three percent $(43.54 \%)$ of the sub-watershed have not undergone changes, which corresponds to an area of 997.77 hectares, with a total area of 2,291.49 hectares. However, 763 hectares or about $33.29 \%$ of the sub watershed have changed and 530.72 ha or $23.16 \%$ conversions Each land use class evolves differently over time. Between 1984 and 1992, fields of peanut and shrub savannah are the most affected by conversions classes respectively $(31.5 \%)$ and $(20.3 \%)$. The changes have affected more dense dry forest $(38.2 \%)$ and shrub savannah $(31.0 \%)$. The changes are much more important in the southern part of the sub watershed. This part is border with Guinea Bissau, it is less secure, so little frequented by the operators of the wood. The exposed paddy, not flooded, have undergone fewer changes. However, $9.4 \%$ of their area is converted into shrub savannah between these two dates. The consequences of different previous droughts causing rural exodus show the decline in agricultural practice naturally giving way to the savannah. 951.87 hectares in the watershed remained stable between 1992 and 2000 representing $41.53 \%$ of its total area.
The most important changes observed during the 1992-2000 period are the changes. These have almost doubled between 1992 and 2000 (37.92\%) of the sub-watershed corresponding to an area of 869.03 hectares compared to period 1984-1992 they accounted for only $23.16 \%$. Tree-savannah and dense dry forest are the two classes that have suffered the most changes with $35.2 \%$ and $33.8 \%$ respectively. The significant improvement in rainfall since the 1990s and the displacement of a large part of the population, because of insecurity, have contributed to the densification of the vegetation in some areas of the watershed. Conversions have largely declined across the sub-watershed over the period 1984-1992, with only $20.53 \%$ corresponding to an area of 470.59 hectares. They affected unequally all land cover classes with a predominance of shrub savannah. Fifty-eight percent $(58 \%)$ of the total area of shrub savannah have passed either the tree-savannah $(26.4 \%)$ or the dense dry forest $(22.3 \%)$ or peanut fields $(8.4 \%)$. Conversions are also more observed in shrub savannah.

Changes in land use between 2000 and 2010 are also dominated by the changes. This has affected all the vegetation in the watershed. Tree-savannah 233.63 hectares of area is changed the vegetation most affected by the change. Tree-savannah has lost 233.67 hectares, 146.63 hectares passed to the dry forest and 87.04 hectares shrub savannah. The change in the dense dry forest in other land use classes is important in the whole sub watershed ( 188.15 hectares) which 148.40 hectares are modified tree savannah $20.7 \%$ and 39.75 hectares of shrub savannah, or 5.5\%. Furthermore, 115.74 hectares of dry forest are converted into fields of peanut between 2000 and 2010. The shrub savannah is less affected by change. The modified total area of 158.01 hectares that are distributed as follows: 82.05 hectares $(21 \%)$ in the dense dry forest and 75.96 hectares (17\%) in tree-savannah.

\section{Discussion}

Examination of the results of the confusion matrices (89-92\%) confirms the low overall confusion in the land cover classes and reliability of the classification. Two reasons for this, the choice of classes based on radiometric values and the choice of training plots and knowledge of the study area have facilitated the images analysis and visual interpretation.However, a few cases of confusion between classes (paddy not flooded, tanne) are noted. This is explained by the fact that the areas of crops are stripped after harvest and thereby, their reflectance is almost similar to that of tanned. The resolution of the Landsat images $(30 \mathrm{~m})$ could also have an influence on the accuracy of the classification of small areas [33]. The study highlighted the dynamics of rice areas and the vegetation cover in the period 1984-2010.

The quantitative results of the land use dynamics show a reduction in the area occupied by the rice areas in the sub watershed, between 1984 and 2000. The rainfall deficit, the lack of adequate facilities, poor management of hydro works agricultural, persistent salinization, technical failures of micro-dams (weirs valves and non-functional) and the silting 
of rice areas, favored by the degradation of vegetation, partly explain the decline of agricultural areas. The absence of flooded paddy, upstream of anti-salt micro dams demonstrates the mismanagement are subject to anti-salt micro-dams. An increase in rice areas is, however noted between 2000 and 2010 in the sub watershed. There is a slight increase as it concerns only $0.2 \%$. The construction of the micro-dam to which is added the improvement in rainfall could explain the increase in rice areas during the period 2000-2010.The results concerning the dynamics of rice areas in the sub watershed are consistent with those found by [34] and [35] in Lower Casamance. By cons, they are not consistent with those found in a previous study on small watersheds in northern Côte d'Ivoire [36], where irrigated rice areas saw increases that are consistent those of [37] obtained in a valley in Morocco. This difference may be due to the fact that the Lower Casamance has no tradition of irrigated rice in contrast to the Ivory Coast and Morocco. It should also be noted also that, unlike ours, which took place over a longer period, the study of [36] was conducted over a short period (1986-1994). As for that of [37], it took into account some of the rainy period (1960-1970). In addition, the rice areas of sub watersheds face salinization and acidification, which is not the case for small sub-watersheds studied by Cecchi and for Valley studied by Hammi. Exploited rice areas are concentrated in lowland and valley slopes, confirming the work of [38].The dense dry forests have experienced an increase in acreage from 1984 to 2010 in the sub watersheds $(7.2 \%)$. Several reasons could explain this increase. The displacement of the population, from the year 1990 because of insecurity, has greatly reduced the impact of human pressure.

A significant change in tree-savannah was observed in 1984-2010 in the watershed. These results show that the vegetation fluctuates in space and in time. Several factors may explain this fluctuation of vegetation. We can note the growing influence of rural activities, the frequency of dry periods and local government strategies and management and conservation of the environment. These findings confirm the studies of [39].

To monitor and map the successive states of the plant cover in sub watershed Agnack, we opted for a diachronic analysis from satellite images processing. The pseudo-headed classification model applied to images is appropriate to the heterogeneous sub watersheds. It allowed us to understand the major trends, in the evolution, of land cover classes. This method was applied in the analysis of dynamic soil occupation Bondoukuy in western Burkina Faso. [40] The effectiveness of this method increases in proportion to the fineness of the spatial resolution of the images. The maximum likelihood algorithm used for classification gives satisfactory results. [41] This method allowed to use human expertise in the successive stages of the classification. A good knowledge of the field is essential. The quantitative results of this study contribute to an objectification of the debate on agricultural water facilities including water management and biodiversity conservation.However, one weakness of this study seems to be the fact that the results of 1984 were validated from the processing of a Landsat image which dates from 1983, a year before, and it is questionable whether relatively dry conditions allow 1983 to reflect the reality of the vegetation in 1984. In addition, the resolution of Landsat images $(30 \mathrm{~m})$ could also affect the accuracy of the classification of small areas [33]. This could explain the low uptake of shrub savannah (5.5\%) in tree- savannah could be explained by the resolution of the used images but also by the rainfall deficit recorded in 1983 .

Thus, this work reveals the potential of remote sensing as a tool to aid in the management of natural resources. In Senegal, as in other developing countries, policymakers often lack information or specialized documents they can use to monitor changes in land use and adjust, if necessary, of developments. Even in case of cartographic materials exist, they are often outdated and incomplete.

\section{Conclusion}

The location and precise measurement of land use changes are important in assessing agrarian dynamics and understand the process that governs them. The results of this work show some ability of remote sensing in the assessment of land use changes. The mapping of land cover between 1984 and 2010 in the sub watersheds studied showed a decrease in rice areas. This is of concern in Lower Casamance where rice is a major player in the food habits and the Diola country tradition. The consequences of irregular rainfall that caused the salinization of land and the lack of suitable facilities have greatly contributed to the gradual abandonment of rice practices. The decline in rice areas, between the years 1984 and 2010 is more worrying in the managed valley in the watersheds Agnack. The results analyzed Landsat images help raise other issues. Indeed, the management of the water retained by the works in watersheds requires more considerations on anthropogenic impacts and real involvement of the beneficiaries. We note in this regard that the insufficient integration of beneficiaries reduces the rate of micro-dams success.

\section{Acknowledgements}

We thank the Project: West African Network for studies of environmental change (WANSEC) of DANIDA-FFU program, 21-08-KU and the Climate Change and Water Program (CCW) for the International Development Research Centre (IDRC) for financial and material support that enabled the completion of this work

\section{References}

[1] Sagna, P. (2005). Climate dynamics and recent developments in the western part of West Africa. Thesis status of Letters. Department. Geography, Faculty of Arts and Social Sciences, University Cheikh Anta Diop of Dakar, 786 pages.

[2] Dacosta, H. (1989). Precipitation and runoff on the Bay of Casamance. 3rd cycle thesis, Faculty of Arts and Social Sciences, University Cheikh Anta Diop of Dakar, 278 pages. 
[3] Sane, T. (2003). Climate variability and its impact on the environment and human activities in high - Casamance. 3rd cycle thesis . Department. Geography, Faculty of Arts and Social Sciences, University Cheikh Anta Diop of Dakar, 366 pages.

[4] Diédhiou, L. (2004). Rice, symbols and development in Lower Casamance Diola . Press for the University of Laval, 339 pages.

[5] Montoroi, J.P. (1996). Sustainable Land Management of the mangrove ecosystem in Casamance ( Senegal ). Dynamics of water and salts in times of drought. Thesis, ORSTOM , Paris, France, 263 pages.

[6] Brunet, D. (1994). Un aménagement hydraulique simple pour la réhabilitation des sols salés : la riziculture en Basse-Casamance, Sécheresse, Volume 5, Numéro 1 :p. 37-44.

[7] Boivin, P., Brunet, D. (1990). Balance of four years of monitoring the salinity of a fitted anti- salt electromagnetic conductivimétrie and kriging valley. Campaign report ORSTOM , 1990,12 pages.

[8] Berton, S. (1988). The flood control in the shallows, small and micro- dams in West Africa . Collection. " Update ", No. 12, GRET, Ministry of Cooperation and Agency for Cultural and Technical Cooperation, Paris , 360 pages.

[9] Aubrun, A. (1987). The amenities in Lower Casamance : examples in the valley Bignona, Senegal. Improvements in irrigation and production systems. Proceedings of the Third Seminar Montpellier, 16-19 December 1986 , Volume I, collection. DSA- CIRAD , Montpellier.

[10] Barry, B. (1987). State of irrigation schemes salty soils of Low Casamance in hydro-agricultural improvements and production systems. Proceedings of the Third Seminar Montpellier, 16-19 December 1986, Volume I, collection. DSA- CIRAD , Montpellier. pp . 241-252.

[11] Marius, C. (1987). The development and management of mangrove soils (Guyana, Indonesia, Senegal). In the irrigation development and production systems. Proceedings of the Third Seminar Montpellier 16-19 December 1986 , Volume I, collection. DSA- CIRAD, Montpellier pp . 265-274.

[12] Marzouk, Y. (1981). History of state and peasant hydraulic designs in Lower Casamance, Senegal, from 1960 to 1990. In peasants and Knowledge Development, G. DUPRE (ed.). Karthala- ORSTOM, Paris, France, p. 61 -97.

[13] Beye, G. (1973). A simple method of desalination soils tans Casamance : mulching. Tropical Agronomy. , 28 , 5, 537-549. 14.

[14] Beye, G. (1975). stock of five years of study of soil desalinization Polder Medina. The Tropical Agronomy, 3, 252-259.

[15] Linares, O.F. (1970). Agriculture and Diola Society. In MacLoughin P. edition, African Food Production System, Baltimore, John Hopkins University Press.

[16] Pelissier, P. (1966). Farmers in Senegal. Agrarian civilizations Kayor in Casamance. Printing Fabrègue, Saint Yrieix, France. Thesis status of geographic, 939 pages.

[17] Ouattara. T., Dubois, J.M., Gwyn, J. (2006). " Methods for mapping land cover in arid environments using multi-source data and vegetation index TSAVI " Remote Sensing Journal, vol. 6 , No. 4 , pp . 291-304.
[18] Lambin, E. (1988). Contribution of satellite remote sensing for the study of agrarian systems and land management in West Africa. Example in Burkina Faso . PhD thesis, Catholic University of Louvain, 239 pages.

[19] Inglada, J. (2001). State of the art in detecting changes on remote sensing images. Toulouse : CNES , 20 pages.

[20] Chavez, P.S., Mackinnon, D.J. (1994). "Automatic detection of vegetation changes in the Southwestern United States using Remotely images." Photogrammetric Engineering and Remote Sensing", Vol . 60, No. 5, pages 571-583.

[21] Muchoney, D.M., Haack, B.N. (1994). "Change detection for monitoring forest defoliation."Photogrammetric Engineering and Remote Sensing, Vol. 60, No. 10, pages 1243-1251.

[22] Song, C., Woodcock, C.E., Seto, K..C., Lenney, M.P, Macomber, S.A. (2001). "Classification and change detection using Landsat TM data: When and how to properly atmospheric effects? " Remote Sensing and general setting, volume 75 , page $30-244$.

[23] Manandhar, R, Odeh, I. O. A., Ancev, T. (2009). Improving the Accuracy of Land Use and Land Cover Classification of Landsat Data Using Post-Classification Enhancement. Remote Sens. 2009, 1, 330-344; doi:10.3390/rs1030330.

[24] Mbow, C., Diaw, A.T. (2003). Choosing spectral indices for mapping vegetation in the middle of savanna. AfricaGIS.

[25] Lamachère, J.M., Puech, C. (1996). Remote sensing, mapping of surface and hydrological modeling. In ORSTOM (eds.) Proceedings of the FAO workshop. Montpellier, 55 pages.

[26] Richter, R. (1997). Correction of atmospheric and topographic effects for high resolution satellite imagery spacial. International Journal of Remote Sensing . Academic Press Inc., New York, 245 pages.

[27] Fotsing, J.M. (1998). Changes in farm systems and dynamic landscapes of west- Cameroon . Analyses multi- scalar relationships Man Area. HDR of Geography and Environment, Paris IV Sorbonne university.

[28] Girard Girard, C. M.C. M. (1999). "Applied Remote Sensing, tropical and tropical zones ", Free Press , Ed . Paris , 529 pages.

[29] Trochain, J. L., (1957). "Inter Agreement on the definition of vegetation types of Tropical Africa." Bulletin of the Institute for the Study Centrafricaines, New Series, no. 13-14, p. 55-93.

[30] Aubreville, A. (1957). Yamgambi agreement on the nomenclature of African vegetation type. Tropical Woods and Forests, (51), p. 23-27.

[31] Adam, J. G. (1962). Contribution to the study of the flora of vegetation of West Africa Basse Casamance: part - Bull. IFAN, ser. 1-25, p. 116- 167.

[32] Monod, T. (1963). "After Yangambi (1956): Note from African phytogeography". Bulletin of the French Institute of Black Africa. Volume XXV, Series A, No. 2, p. 215-265.

[33] Bamba, I. (2010). Anthropisation and spatiotemporal dynamics of forest landscapes in the Democratic Republic of Congo. PhD thesis, University of Brussels, 205 pages.

[34] Bosc, P.M. (2005). At the crossroads of powers. A peasant organization faces resource management (Lower Casamance, Senegal). I.R.D. Publishing, Collection through fields, Paris, $310 \mathrm{p}$. 
[35] Ecoutin, JM, Barry, B., S. Bouju, Charles-Dominique, E., Journet, O., Penot, E. Street, O., D. Souaré, Sow, M. (1999). Technical environmental design, in Cormier-Salem M.-C. ed, Rivers South. Companies and West African mangroves. Paris: IRD editions, 209-268.

[36] Cecchi, P., Gourdin, F., Kone, S., Corbin, D., Etienne, J., Casenave, A. (2009). Small dams in northern Ivory Coast: inventory and hydrological potentials. Secheresse, 2009, Volume 20, Number1: p. 112-22.

[37] Hammi, S., Simonneaux, V., Alifriqui, M. Auclair, L., Montes, N. (2007). Evolution of forest recoveries and land use between 1964 and 2002 in the upper valley of Ait Bouguemez (Central High Atlas, Morocco) and Impact of management. Secheresse, Volume 18, Number 4: p. 271-277.
[38] Sawadogo, A., Zombre, NP, Bock L. Lacroix, D. (2008). Evolution of land use Ziga in Yatenga (Burkina Faso) from aerial photos. Remote Sensing Journal, 2008, Vol. 8, No. 1, p. 59-73.

[39] Vasconcelos, M.J.P., Mussa Biai, J.C., Araujo A., Diniz, M.A. (2002). Land cover change in two protected areas of Guinea-Bissau (1956-1998), Applied Geography, 22 (2), p.139-156, Apr 2002.

[40] Bruneau, J. (2000). Evolution of agricultural space to Bondoukuy (western Burkina Faso) between 1990 and 1998 from images Spot. DEA Time Environment Space Company (ARE), University of Orleans.

[41] Tsayem Demaze, M. (2002). Characterization and monitoring deforestation in tropical environments through remote sensing: application to agricultural clearing in French Guiana and Brazil. PhD thesis, University of Orleans. 